\title{
MULTIPLE FLUIDS IN DAMOND COAT AND THEIR ROLE IN DIAMOND GROWTH.
}

\author{
E.L. Tomlinson, A.P. Jones, H.J. Milledge and A.D. Beard \\ Department of Earth Sciences, University College London, UK.
}

This work is an assessment of the role of fluids in diamond growth using mantle fluid compositions measured in micro-inclusions in coated diamond. Coated diamonds comprise a clear octahedral core surrounded by an overgrowth of inclusion-rich octahedral diamond. Navon and Hutcheon [1] recognized that micro-inclusions contain fluids rich in $\mathrm{H}_{2} \mathrm{O}, \mathrm{CO}_{3}{ }^{2-}, \mathrm{SiO} 2, \mathrm{~K}_{2} \mathrm{O}, \mathrm{CaO}$ and $\mathrm{FeO}$, present in bulk proportions that resemble potassic magmas. Schrauder and Navon [2] studied the composition of individual inclusions, noting that they vary linearly between a carbonatitic and a hydrous end-member. A third fluid type, a $\mathrm{KCl}$ brine, was identified in cloudy diamonds [3], this fluid was thought to be distinct from the two end-members described in fibrous diamonds.

\section{EMPA AND FTIR DATA}

Electron-microprobe and infrared spectroscopy results for coated diamonds from the Democratic Republic of Congo, indicate that all 3 fluids are present in the diamond micro-inclusions. The fluid compositions lie along two continua (figure 1):

Carbonatite-Silicate Series: Span a continuum between 1) a carbonatite-like (rich in $\mathrm{CaO}, \mathrm{P}_{2} \mathrm{O}_{5}, \mathrm{FeO}$ and $\mathrm{MgO}$ ) and 2) an alkali silicate (rich in $\mathrm{SiO}_{2}, \mathrm{Al}_{2} \mathrm{O}_{3}, \mathrm{~K}_{2} \mathrm{O}$ and $\mathrm{TiO}_{2}$ ) end-member with roughly $\mathrm{K}$-feldspar stoicometry. $\mathrm{SiO}_{2}$ correlates with the other major elements, suggesting a mixing relationship. The presence and abundance inclusions without $\mathrm{K}-\mathrm{Cl}$ indicates that these end-members mixed before the involvement of $\mathrm{K}-\mathrm{Cl}$.

K-Cl fluid-Silicate Series: Span a continuum between 1) the alkali silicate end-member and 2) an end member rich in $\mathrm{K}$ and $\mathrm{Cl}$. There is a positive correlation between $\mathrm{Cl}$ and $\mathrm{K}_{2} \mathrm{O}$ (also between $\mathrm{Cl}$ and $\mathrm{Na}_{2} \mathrm{O}$ ), but the trends for the other major elements are the same as the carbonatite-silicate series. The calculated $\mathrm{Cl}$ endmember composition is similar to the "brine" identified in cloudy diamonds [3]. These inclusions are preferentially located at the core-coat boundary, suggesting that the $\mathrm{K}-\mathrm{Cl}$ fluid is involved early in coat growth.
A fourth fluid end-member, rich in sulfur, has also been identified (figure 1). Diamonds whose bulk inclusion compositions fall towards the silicate end-member contain more $\mathrm{H}_{2} \mathrm{O}$ than the carbonatite-like endmember.

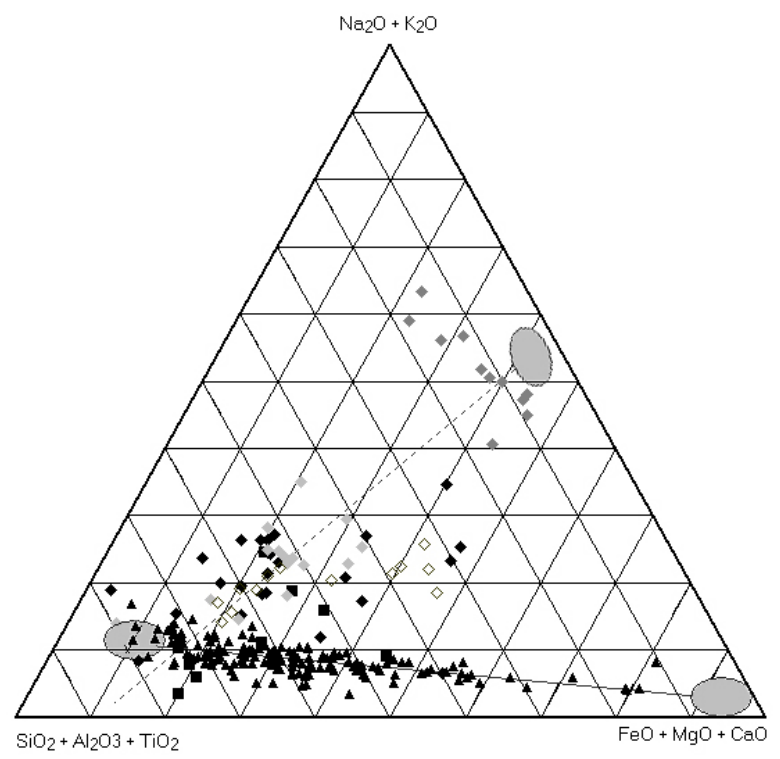

Figure 1: Individual inclusion compositions grouped into series. - Carbonatite-silicate series; $\boldsymbol{\Delta}$ - Silicate K-Cl series; - - S-rich. Also shown, $\bigcirc$ - calculated series endmember compositions, and published data for inclusions in fibrous diamond: - Zaire and Botswana [1]; $\diamond$ - Jwaneng, Botswana [2]; - Brine in cloudy diamond, Koffiefontein, South Africa [3].

\section{EXPERIMENTAL WORK}

The presence of several fluids in the diamond growth environment raises questions regarding the effect of fluid composition on diamond nucleation, growth rate, and inclusion entrapment. Moreover, what is the effect of having just one or two of the natural fluids present in the growth environment - might one or more of these fluids be involved in the growth of "normal" octahedral diamond?

Diamond synthesis experiments using $\mathrm{H}_{2} \mathrm{O}-\mathrm{CO}_{2}$ fluid have been successful at $7.7 \mathrm{GPa}, 1600^{\circ} \mathrm{C}$ [4], and 
diamonds have been synthesized using $\mathrm{KCl}$ at $6 \mathrm{GPa}$, $1620^{\circ} \mathrm{C}$ [5]. However, the role of each of the fluids in terms of nucleation, growth rate, morphology, and inclusion entrapment, and the effect of variable degrees of interaction between end-members have not previously been addressed. Results will be presented from High Pressure-High Temperature Multi-Anvil Press experiments extending previous work into fluid regimes. The advantage of fluid systems is that the minimum synthesis temperature is not controlled by the catalyst melting temperature, therefore pressuretemperature conditions may potentially approach those of natural diamond growth $\left(5-6 \mathrm{GPa}, 900-1200^{\circ} \mathrm{C}\right)$.

Information on fluids is relevant to attempts to characterize diamonds sourced from different mantle and geographical regions, and broadens the list of substances from which synthetic diamonds may be produced. Fluids cause mantle metasomatism and, since fluids are responsible for the transport of volatiles between mantle reservoirs, they influence the trace and isotopic signatures of those reservoirs.

\section{REFERENCES}

Navon, O., Hutcheon, I.D., Rossman, G.R., Wasserburg, G.J., 1988. Mantle-derived fluids in diamond microinclusions. Nature 335, 784-789.

Schrauder, M., O. Navon, 1994. Hydrous and Carbonatitic Mantle Fluids in Fibrous Diamonds from Jwaneng, Botswana. Geochimica et Cosmochimica Acta 58(2), 761-771.

Izraeli, E.S., Harris, J.W., Navon, O., 2001. Brine inclusions in diamonds: a new upper mantle fluid. Earth and Planetary Science Letters 187(3-4), 323-332.

Akaishi, M., et al., Formation process of diamond from supercritical $\mathrm{H} 2 \mathrm{O}-\mathrm{CO} 2$ fluid under high pressure and high temperature conditions. Diamond and Related Materials, 2000. 9(12): p. 1945-1950.

Wang, Y., Kanda, H., 1998. Growth of HPHT diamonds in alkali halides: possible effects of oxygen contamination. Diamond and Related Materials, 1998. 7(1), 57-63.

Contact: E Tomlinson Department of Earth Sciences, University College London, Gower Street, London, WC1E 6BT, United Kingdom, , E-mail: emma.tomlinson@ucl.ac.uk 